Invited Paper

\title{
Synthesis of Imidazo[4,5-b]quinoxaline Ribonucleosides as Linear Dimensional Analogs of Antiviral Polyhalogenated Benzimidazole Ribonucleosides
}

\author{
Zhijian Zhu ${ }^{+}$, Sunita Saluja ${ }^{*}$, John C. Drach and Leroy B. Townsend* \\ Department of Chemistry, College of Literature, Sciences, and Arts; Department of Medicinal Chemistry, \\ College of Pharmacy; and Department of Biologic and Materials Sciences, School of Dentistry, \\ University of Michigan, Ann Arbor, Michigan 48109-1065, U.S.A.
}

\begin{abstract}
We have recently found that 2,5,6-trichloro-1-( $\beta$-D-ribofuranosyl)benzimidazole ('CRB) and the corresponding 2-bromo analog have better in vitro activities against HCMV than the clinically used agents ganciclovir and foscarnet. These benzimidazole nucleosides act by a unique mechanism, however, their biological target has not been completely identified. As an approach to probing the target, we have designed imidazo $[4,5-b]$ quinoxaline nucleosides as linear dimensional analogs of the benzimidazole nucleosides to study the spatial limitation of the binding site in the target enzyme. A convenient route was developed for the synthesis of 2-substituted 6,7-dichloroimidazo[4,5-b]quinoxalines involving a reaction of 2,3,6,7tetrachloroquinoxaline with ammonia followed by a ring annulation as the key step. This furnished the versatile heterocycle 6,7-dichloroimidazo[4,5-b]quinoxalin-2-one. Ribosylation of 2-substituted imidazo[4,5b]quinoxalines was influenced by the functional group at the 2-position and the 2-one compound was found to smoothly undefgo ribosylation. The 2-one group of the nucleoside was converted into specifically selected 2-substituted compounds. Evaluation of the compounds for activity against two herpesviruses and for cytotoxicity showed they were less active and/or more cytotoxic than TCRB. We conclude therefore, that the binding pocket on the protein target of TCRB will tolerate some electronic and size changes.
\end{abstract}

\section{INTRODUCTION}

Human cytomegalovirus (HCMV) is a human herpes virus which has a high order of genome sequence complexity and a narrow host range.' Although HCMV is innocuous in the immunocompetent individual, it is a significant pathogen in neonates and immunocompromised individuals ${ }^{2}$ such as bone marrow ${ }^{3}$ and organ transplant $t^{4}$ patients as well as individuals with acquired immune deficiency syndrome (AIDS). ${ }^{5}$ Ganciclovir, foscarnet and cidofovir are the only drugs approved by the United States Food and Drug Administration for the treatment of HCMV infections. However, all of them have poor bioavailability and side efrects. ${ }^{6}$ Moreover, HCMV strains resistant to ganciclovir and foscarnet have been reported. ${ }^{7}$ Moreover, $\mathrm{co}^{-a d m i n i s t r a t i o n ~ o f ~}$ ganciclovir and zidovudinc (AZF) was found to cause synergistic toxicity both in vitro and in AIDS patients. ${ }^{\varnothing}$ Consequently, there is a need for better, more potent and selective antiviral drugs to treat HCMV infections.
Recently in our laboratory, a series of polyhalogenated benzimidazole ribonucleosides were found to have potent activity and high selectivity against human cytomegalovirus (HCMV) ${ }^{9,10}$ The lead compounds 2,5,6-trichloro-1-( $\beta$-Dribofuranosyl)benzimidazole (TCRB, 1a) and 2-bromo-5,6dichloro-1-( $\beta$-D-riboturanosyl)benzimidazole (BDCRB, lb) were more active and less cytotoxic than ganciclovir, foscarnet, and the 2-unsubstituted benzinidazole ribonucleoside DRB (1f) ${ }^{9,11,12}$ Furthermore, both compounds were found to act by a unique mechanism which does not involve inhibition of DNA synthesis but does involve inhibition of DNA processing. ${ }^{13}$ Beside TCRB, BDCRB, and the related 2-isopropylamino-L-riboside analog of TCRB (1263W94), ${ }^{14}$ derivatives with other substituents such as benzylthio (1c), cyclopropylamino (1d) and isopropylamino (1e), at the 2-position were also found to be active against HCMV. . $^{10.14}$

In an effort to investigate the spatial limitations of the binding site of the targeted enzyme to the heterocyclic agly-

Present addresses: +Parke-Davis Pharmaceutical Research, Division of Wamer-Lambert, 2800 Plymouth Road, Ann Arbor, Ml 48105.

"Department of Chemistry, Hunter College of the University of New York, New York, NY 10021. 
con of the benzimidazole ribonucleosides 1 , we have synthesized a series of imidazo[4,5-b]quinoline ribonucleosides. ${ }^{15}$ These compounds were designed as linear dimensional analogs of 1 with an electron withdrawing pyridine ring as the spacer. In that study, both the N1 (2) and the $\mathrm{N} 3$ (3) isomers of the imidazo[4,5-b]quinoline ribonucleosides were prepared to assess the possible effects of the pyridine-spacer in addition to the spatial and electronic effects on the biological activities. It was found that, in general, the N1-isomers (2) were active against HCMV and had some separation between activity and toxicity whereas the corresponding $\mathrm{N}^{3}$ isomers (3) were either inactive or showed no separation between activity and toxicity. ${ }^{15}$ These results demonstrated that in addition to the designed spatial and electronic effects, there must be other factors which play an important role on the observed biological activity. This difference in the biological activity, due to the use of a pyridine ring as a spacer, should be the result of an inherent structural difference between 2 and 3 . The difference between $\mathbf{2}$ and $\mathbf{3}$ involves the different relative location of the pyridine nitrogen. On one hand, this nitrogen offers the possibility for an additional hydrogen-bonding site, and on the other, generates different steric interactions between the ribosyl moiety and the aglycon which could affect the most favorable conformation of the nucleosides.

To continue our study on the linear dimensional analogs of benzimidazole ribonucleosides with electron-withdrawing spacers and to identify the factor(s) which cause(s) the different antiviral activity observed between 2 and 3, a series of imidazo[4,5-b]quinoxaline ribonucleosides (4) was sclected. These pyrazino-separated dimensional analogs (4) have additional nitrogens in the spacer on either side of the aglycon. This introduction of a pyrazine ring system would have the same steric interaction between the aglycone and the ribosyl moiety as proposed for 3 and the

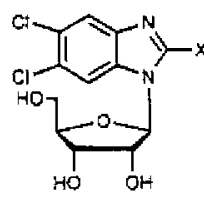

1

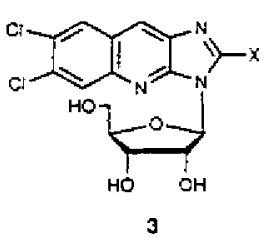

3

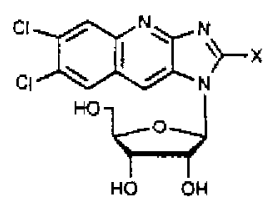

2

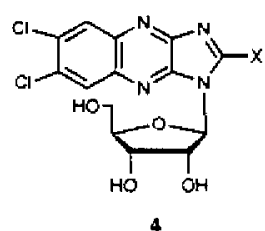

4
$X=C l$ (a), $\mathrm{Br}$ (b), benzyithio (c), cyclopropylamiso (d), isopropylamino (e), $H(f)$

Fig. 1. hydrogen-bonding potential as proposed for 2 . Thus, these compounds have the potential to interact with a biological target in a unique manner.

\section{RESULTS AND DISCUSSION}

\section{Chemistry}

Using the same strategy as in the previous synthesis of 2 and 3 , we selected a route in which the substituents at the 2-position of 4 would be generated from an appropriate intermediate in the final steps of the synthesis. The ribonucleoside of 6,7-dichloroimidazo[4,5-b]quinolin-2-one (8a) was chosen as the immediate precursor since the compound was expected to be fairly stable and contains a versatile functional group at the 2-position. We elected to use $2,3,6,7$-tetrachloroquinoxaline ${ }^{16}(5)$ as our starting material for the synthesis of the heterocycle 6,7-dichloroimidazo[4,5-b]quinoxalin-2-one (7). Compound 5 was converted into 2,3-diamino-6,7-dichloroquinoxaline (6) by the treatment of 5 with ammonia at $90^{\circ} \mathrm{C}$. Compound 6 was ring closed by using carbonyl diimidazole in toluene at reflux to give 7. Attempts to use urea for the conversion ${ }^{17}$ of 6 to 7 failed, most likely due to the electron withdrawing effect of the two chloro substituents.

Although the synthesis of imidazo[4,5-b]quinoxalines has been studied extensively, ${ }^{18}$ to the best of our knowledge there have been no reports on the synthesis of imidazo[4,5b]quinoxaline nucleosides. The ribosylation of 7 was achieved under Vorbruggen conditions. ${ }^{19}$ When 7 was silylated with $N, O$-bis(trimethylsilyl)acetamide (BSA) followed by the addition of 1- $O$-acetyl-2,3,5-tri- $O$-benzoyl- $\beta$ D-ribofuranose (TBAR) and trimethylsilyl tritluoromethylsulfonate (TMSOTf), 6,7-dichloro-1-(2,3,5-tri- $O$-benzoyl$\beta$-D-ribofuranosyl)imidazo[4,5-b]quinoxalin-2-one (8a) was obtained in $88 \%$ yield as the only product. Deprotection of $8 \mathbf{a}$ with methanolic ammonia gave 6,7-dichloro-1( $\beta$-D-ribofuranosyl)imidazo[4,5-b]quinoxalin-2-one (8b). The regiochemical assignment of $\mathbf{8 b}$ was accomplished by using selective ${ }^{1} \mathrm{H}_{-}{ }^{13} \mathrm{C}$ decoupling. ${ }^{20}$ First, the three most down-field carbon-13 peaks (153.64, 141.81 and 141.12 $\mathrm{ppm}$ ) were identified as the three carbons on the imidazole moiety since they are the only three aromatic carbons which are not coupled to both $\mathrm{H} 5$ and $\mathrm{H} 9$. When the anomeric proton of $8 \mathbf{b}$ was irradiated, carbon-13 peaks at $153,64 \mathrm{ppm}$ and $141.12 \mathrm{ppm}$ were decoupled which indicated that the ribosy! moiety was attached at the N1 position. The $\beta$-configuration of $\mathbf{8 b}$ was confirmed by the NOE enhancement observed between $\mathrm{Hl}^{\prime}$ and $\mathrm{H}^{\prime}$ '.

Preparation of the target analogs (4) were approached 


\section{Scheme I}
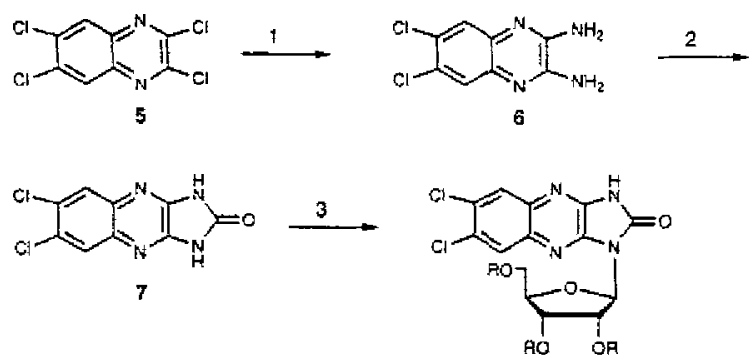

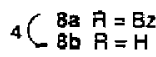

1) $\mathrm{NH}_{3}, 90^{\circ} \mathrm{C} .95 \%$. 2) cartonyl dilnidazole, teluene, raflux $63 \%$. 3) (a) $85 \mathrm{~A}_{2} \mathrm{CH}_{3} \mathrm{CN}$, f.t.: (b) TEAR. TMSOT, $50^{\circ} \mathrm{C} ; 88 \%$. 4) $\mathrm{NH}$, MeOH. r.t. $57 \%$.

by a functional group transformation at the 2-position of $8 \mathbf{a}$. When 8a was treatcd with $\mathrm{POCl}_{3} / 1,2,4$-triazole/Et $\mathrm{N}_{3} \mathrm{~N}^{21}$ in acetonitrile at room temperature for 40 hours, 8a was converted into the 2 -triazolyl derivative 9 . Compound 9 was found to be quite unstable and was hydrolyzed to 8a during silica gel chromatography and extraction. Therefore, compound 9 was prepared and without isolation, it was converted into 2-cyclopropylamino-6,7-dichloro- 1 - (2,3,5-tri$O$-benzoyl- $\beta$-D-ribofuranosyl)imidazo[4,5-b]quinoxaline (10) and 6,7-dichloro-2-isopropylamino-1-(2,3,5-tri- $O$ benzoyl- $\beta$-D-ribofuranosyl)imidazo[4,5-b]quinoxaline (11) by the addition of cyclopropylamine and isopropylamine, respectively. Compound 10 and 11 were deprotected with methanolic ammonia to afford $4 d$ and $4 \mathbf{e}$, respectively. When compound 9 was treated with hydrogen sulfide, we obtained 6,7-dichloro-1-(2,3,5-tri- 0 -benzoyl- $\beta$-D-ribofuranosyl)imidazo[4,5-b]quinoxalin-2-thione (12a). A removal of the protecting groups furnished 6,7 -dichloro-1-( $\beta$-D-ribofuranosyl)imidazo $[4,5-b]$ quinoxalin-2-thione $(12 b)$. 2Benzylthio- 6,7 -dichloro-1-( $\beta$-D-ribofuranosyl)imidazo $[4,5-$ b]quinoxaline (4c) was prepared by the benzylation of $\mathbf{1 2 b}$ with benzyl bromide. The DRB analog, 6,7-dichloro-1- $(\beta$ D-ribofuranosyl)imidazo[4,5-b]quinoxaline (4f), was prepared from $12 b$ by Raney nickel desulfurization. The conversion of a thio or alkylthio group to a chloro group by chiorine has been found to be an efficient and facile method for the generation of chloro substituted nucleosides ${ }^{22}$ and been successlutly used ${ }^{23}$ in the prepatation of $2 \mathbf{a}$ and $3 \mathbf{a}$. However, attempts to convert the 2-thio group to a chloro group on both $12 \mathrm{a}$ and $\mathbf{1 2 b}$ were found to be unsuccessful due to the hydrolysis of the product during work-up. This facite hydrolysis was most likely due to the electron withdrawing effect of the additional ring nitrogen.

\section{Biology}

The antiviral activity and cytotoxicity of the imi-

\section{Scheme II}

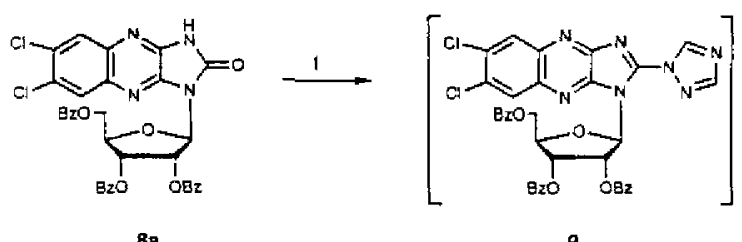

$8 \mathbf{a}$
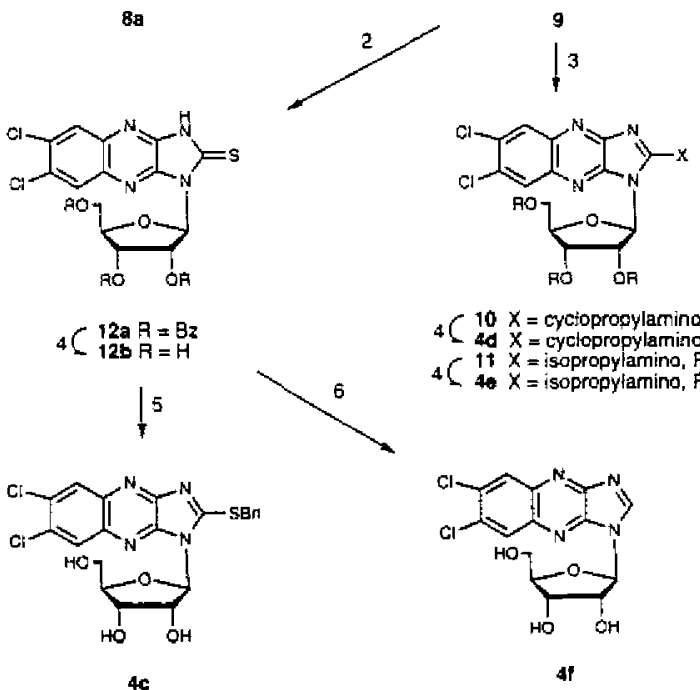

4C $10 X=$ cyciopropylamino, $\mathrm{A}=\mathrm{Bz}$ 4 4d $X=$ cyctopropylamino, $P=H$ $4 C \begin{aligned} & 11 X=\text { isopropylamino, } R=B z \\ & \text { 40 } X=\text { isopropylamino, } R=H\end{aligned}$
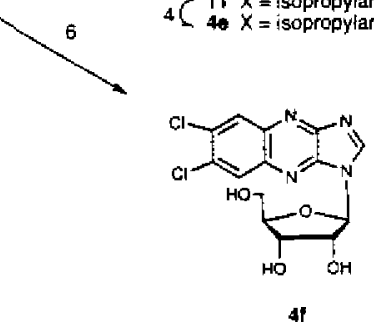

1) POCl iriazole. El, N, r.t, 2) $\mathrm{H}_{2} \mathrm{~S}, 79 \%$ from 8. 3) cyclooropylamine or isopropylamine

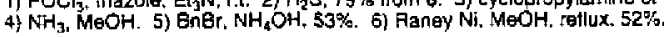

dazo[4,5-b]quinoxaline ribonucleosides (4c-f) were determined and compared to the corresponding benzimidazole ribonucleosides. Activity against HCMV and herpes simplex virus type 1 (HSV-I) was determined using a plaque reduction assay for the former virus and an ELISA for the latter. 'Two cytotoxicity assays were used which involved visual inspection of stationary buman foreskin fibroblasts and growing $\mathrm{KB}$ cells (Table 1). The benzylthio derivative $4 c$ was found to be five times more active than the corresponding benzimidazole ribonucleoside $1 \mathrm{c}$ but also about 5 times more cytotoxic. The cyclopropylamino derivative 4d likewise was somewhat more active against HCMV than the benzimidazole ribonucleoside 1d. The isopropylamino derivative $4 \mathrm{e}$ was about as active and cytotoxic as $\mathbf{4 d}$. Compared to the corresponding $\mathrm{N} 1$ isomer of imidazo[4,5-b]quinoline ribonucleosides, $4 c$ and $4 \mathrm{e}$ showed essentially the same activity as the imidazo[4,5-b]quinoline ribonucleosides ${ }^{15}$ whereas $4 d$ was more effective. None of the imidazo[4,5-b]quinoline nor the imidazo[4,5-b]quinoxaline ribonucleosides, however, were as active against HCMV at non-cytotoxic concentrations as was TCRB (Table 1).

The antiviral activity of these imidazo[4,5-b]quinoxaline ribonucleosides demonstrated that a linear extension of the aglycon of benzimidazole ribonucleosides with a pyrazine spacer essentially retains some antiviral activity 
Table 1. Antiviral Activity and Cytotoxicity of Benzimidazole and Imidazo[4,5-b]quinoxaline Ribonucleosides
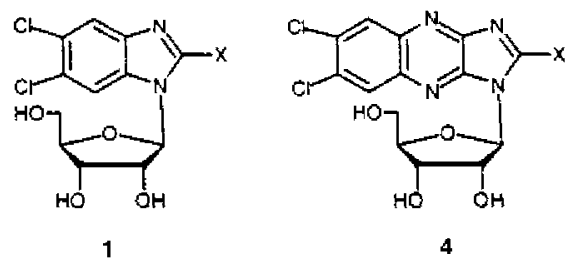

\begin{tabular}{l}
\hline \\
\end{tabular}

compared to the benzimidazole nucleosides. For the benzylthio and the isopropylamino derivatives, essentially the same activity profile was observed between $2 c$ and $4 c, 2 e$ and $4 \mathbf{e}$ (in sharp contrast with $3 \mathrm{c}, 3 \mathrm{e}$ ). This has implied that, most likely, the additional binding through the N4 of these analogs is crucial for their antiviral activity. On the other hand, at least for the benzylthio and isopropylamino derivatives, the conformational difference generated by the different steric interaction between the aglycones and the ribosyl moiety was minimal. We conclude, therefore, that the binding pocket on the target enzyme for the benzimidazole ribonucleosides can tolerate the spacer between the imidazole and benzene tings.

\section{EXPERIMENTAL SECTION}

\section{General Chemical Procedures}

Melting points were taken on a Thomas Hoover apparatus and are uncorrected. Silica gel 60 230-400 mesh (E.
Merck, Darmstadt, West Germany) was used for chromatography. Thin Layer Chromatography (TLC) was performed on prescored SilicAR 7GF plates (Analtech, Newark, DE, USA). Compounds were visualized by illumination under UV light ( $254 \mathrm{~nm})$. Evaporations were carried out under reduced pressure (water aspirator) with the bath temperature below $40^{\circ} \mathrm{C}$, unless specified otherwise. UV spectra were performed on a Hewlett-Packard 8450-A UV/VIS spectrophotometer. Nucleat magnetic resonance (NMR) spectra were determined at $360 \mathrm{MHz}$ with a Bruker WP360 SY. The chemical shift values are expressed in $\delta$ values relative to the chemical shift of TMS or the solvent used. Elemental analyses were performed by $M-H-W$ Laboratories, Phoenix, $A Z$.

\section{2,3-Diamino-6,7-dichloroquinoxaline (6)}

$2,3,6,7$-Tetrachloroquinoxaline $(5,1.0 \mathrm{~g}, 3.67 \mathrm{mmol})$ and liquid ammonia $(20 \mathrm{~mL})$ was heated in a steel bomb at $90^{\circ} \mathrm{C}$ for 6.12 hours. The steel bomb was cooled to room temperature and ammonia was allowed to evaporate. The solid was triturated with water $(30 \mathrm{~mL})$, collected by filtra- 
tion, washed with water and dried at $75{ }^{\circ} \mathrm{C}$ to give 2,3 diamino-6,7-dichloroquitioxaline $(6,0.83 \mathrm{~g}, 95.6 \%)$. Compound 6 was dissolved in boiling DMF followed by the addition of ice water. The fine yellow crystals were collected, washed with water and dried for analysis: $\mathrm{Mp}:>260^{\circ} \mathrm{C},{ }^{1} \mathrm{H}$ NMR (DMSO- $\left.d_{6}\right): \delta 7.45(\mathrm{~s}, 2 \mathrm{H}), 6.98\left(\mathrm{bs}, 4 \mathrm{H}, \mathrm{D}_{2} \mathrm{O} \mathrm{ex}-\right.$ changeable). Anal. Calcd for $\mathrm{C}_{8} \mathrm{H}_{6} \mathrm{~N}_{4} \mathrm{Cl}_{2}: \mathrm{C}, 41.94 ; \mathrm{H}, 2.63$; $\mathrm{N}, 24.45$. Found: $\mathrm{C}, 42.00 ; \mathrm{H}, 2.65 ; \mathrm{N}, 24.46$.

\section{6,7-Dichloroimidaze[4,5-b]quinoxalin-2-one (7)}

2,3-Diamino-6,7-dichloroquinoxaline $(6,0.226 \mathrm{~g}, 1.0$ mmol) and carbonyldimidazole $(0.195 \mathrm{~g}, 1.2 \mathrm{mmol})$ in 15 $\mathrm{mL}$ of freshyy dried toluene were heated at reflux for 4 hours. The suspension was cooled to room temperature and the solid was colfected by filtration. The solid was stirred in $20 \mathrm{~mL}$ of water at room temperature for 2 hours, collected by filtration, and dried under vacuum at $78{ }^{\circ} \mathrm{C}$ overnight to give 6,7-dichloroimidazo[4,5-b] quitoxalin-2-one (7, 0.159 $\mathrm{g}, 63 \%$ ) as a slightly brown solid. Mp: decompose above $400^{\circ} \mathrm{C}$. ${ }^{1} \mathrm{H}$ NMR (DMSO- $\left.d_{6}\right): \delta 12.123(\mathrm{~s}, 2 \mathrm{H}), 8.048(\mathrm{~s}$, $2 \mathrm{H}$ ). ${ }^{13} \mathrm{C}$ NMR (DMSO- $\left.d_{6}\right): \delta 155.19,143.08,137.88$, $128.34,128.00$. UV $\left[\lambda_{\max }, \mathrm{nm}(\mathrm{E})\right]:(\mathrm{MeOH}) 350.6(19100)$, $343.0(14600), 334.8(17200), 255.8$ (17600), 220.6 (44700). Anal. Calcd for $\mathrm{C}_{9} \mathrm{H}_{4} \mathrm{~N}_{4} \mathrm{OCl}_{2}: \mathrm{C}, 42.35 ; \mathrm{H}, 1.57$; $\mathrm{N}, 2$ 21.96. Found: $\mathrm{C}, 42.50 ; \mathrm{H}, 1.60 ; \mathrm{N}, 21.72$.

\section{6,7-Dichloro-1-(2,3,5-tri- $O$-benzoy1- $\beta$-D-ribofuranosyl)- imidazo[4,5-b]quinoxalin-2-one (8a)}

Bis(trimethylsilyl)acetamide (BSA, $1.7 \mathrm{~mL}, 6.75$ mmol) was added to a suspension of 6,7 -dichloroimidazo[4,5-b]quinoxalin-2-one $(7,0.782 \mathrm{~g}, 3.07 \mathrm{mmol})$ in dry acetonitrile $(100 \mathrm{~mL})$ and the suspension was stirred at room temperature for 30 minules. $1-O$-Acctyl-2,3,5-tri- $O$ benzoyl- $\beta$-D-ribofuranose ( $1.62 \mathrm{~g}, 3.22 \mathrm{mmol}$ ) was added tollowed by trimechylsilyl triffuoromethanesulfonate (TMSOTf, $1.3 \mathrm{~mL}, 6.1 \mathrm{mmol}$ ). After the reaction was stirred at $50^{\circ} \mathrm{C}$ for 15 minutes, an additional quantity of TMSOTf $(0.65 \mathrm{~mL}, 3.05 \mathrm{mmol})$ was added. The reaction mixture was stirred at $50^{\circ} \mathrm{C}$ for an additional 10 minutes to give a clear solution and then stirred at room temperature overnight. The reaction solution was concentrated under reduced pressure to about $30 \mathrm{~mL}$ and then diluted with ethyl acetate $(200 \mathrm{~mL})$. The ethyl acetate solution was washed with a saturated sodium bicarbonate solution $(3 \times 50 \mathrm{~mL})$, a saturated sodium chloride solution $(50 \mathrm{~mL})$ and dried over anhydrous sodium sulfate. The solvent was cyaporated, the residue was subjected to silica gel flash chromatography and eluted with $0.5 \%$ methanol in chloroform. The appropriate tractions, as determined hy TLC, were collected and the solvent was evaporated to give 6,7-dichloro-1-(2,3,5-tri-
$O$-benzoyl- $\beta$-D-ribofuranosyl)imidazo[4,5- $b$ ]quinoxalin-2one $(\mathbf{8 a}, 1.875 \mathrm{~g}, 88 \%)$ as a white powder: $\mathrm{Mp}: 232-235^{\circ} \mathrm{C}$. ${ }^{1} \mathrm{H}$ NMR (CDCl$): \delta 10.45$ (s, 1H), 8.040 (s, $\left.1 \mathrm{H}\right), 7.906$ (s, $2 \mathrm{H}), 8.055-7.283(\mathrm{~m}, 15 \mathrm{H}), 6.659(\mathrm{q}, J=3.76 \mathrm{~Hz}, J=6.0$ $\mathrm{Hz}, 1 \mathrm{H}), 6.43(\mathrm{~d}, J=3.6 \mathrm{~Hz}, 1 \mathrm{H}), 6.418(\mathrm{q}, J=6.3 \mathrm{~Hz}, J=$ $8.0 \mathrm{~Hz}, 1 \mathrm{H}), 4.898(\mathrm{dd}, J=11.8 \mathrm{~Hz}, J=3.5 \mathrm{~Hz}, 1 \mathrm{H}), 4.814$ $(\mathrm{m}, 1 \mathrm{H}), 4.726(\mathrm{q}, J=11.8 \mathrm{~Hz}, J=4.7 \mathrm{~Hz}, 1 \mathrm{H})$. Anal. Calcd for $\mathrm{C}_{35} \mathrm{H}_{24} \mathrm{H}_{4} \mathrm{O}_{8} \mathrm{Cl}_{2}: \mathrm{C}, 60.09 ; \mathrm{H}, 3.43 ; \mathrm{N}, 8.01$. Found: $\mathrm{C}$, $60.31 ; 11,3.52 ; \mathrm{N}, 7.84$.

\section{6,7-Dichloro-1-( $(\beta-D-r i b o f u r a n o s y l) i m i d a z o[4,5-b] q u i n o x-$ alin-2-one (8b)}

6,7-Dichloro-1-(2,3,5-tri- $O$-benzoyl- $\beta$-D-ribofuranosy1)imidazo[4,5-b]quinoxalin-2-one ( $8 \mathbf{a}, 0.2 \mathrm{~g}$ ) was stirred in a saturated methanofic ammonia solution $(100 \mathrm{~mL})$ at room temperature for 24 hours. The solvent was evaporated under reduced pressure and the solid was triturated with hexane ( 3 $\times 30 \mathrm{~mL}$ ). The hexane was decanted and the solid was dried under $0.01 \mathrm{mmHg} / 78^{\circ} \mathrm{C}$ for 24 hours and then recrystallized from acetonitrile/methanol $(10 \mathrm{~mL} / 5 \mathrm{~mL})$ to give 6,7 . dichloro-1-( $\beta$-D-ribofuranosyl)imidazo[4,5-b]quinoxalin2-one $(8 \mathrm{~b}, 0.063 \mathrm{~g}, 57 \%)$ as a white solid. $\mathrm{Mp}: 216-218^{\circ} \mathrm{C}$. ${ }^{1} \mathrm{H}$ NMR (DMSO- $\left.d_{6}\right) ; \delta 12.670(\mathrm{bs}, \mathrm{IH}), 8.189(\mathrm{~s}, \mathrm{IH})$, $8.072(\mathrm{~s}, 1 \mathrm{H}), 5.803(\mathrm{~d}, J=5.5 \mathrm{~Hz}, 1 \mathrm{H}), 4.279(\mathrm{~m}, 1 \mathrm{H})$, $3.896(\mathrm{~m}, 1 \mathrm{H}), 3.689(\mathrm{~m}, 1 \mathrm{H}), 3.537(\mathrm{~m}, 1 \mathrm{H})$. Irradiation of $\mathrm{H}^{\prime}$ (5.803 ppm) gave a $1.4 \%$ NOE enhancement of $\mathrm{H}^{\prime}$ $(3.896 \mathrm{ppm})$ while irradiation of $\mathrm{H}^{\prime}$ gave a $1.8 \%$ NOE enhancement of $\mathrm{Hl}^{\prime} .{ }^{13} \mathrm{C}$ NMR (DMSO- $d_{6}$ ): $\delta 153.64,141.81$, $141.12,137.69,136.85,129.08,128.78,128.11,127.89$, $85.76,85.25,70.65,70.54,61.96$ UV $\left[\lambda_{\max }, \mathrm{nm}(\varepsilon)\right]$ : (MeOH) $352.6(20500), 336.6(17500), 256.6(21200)$, 222.0 (44700). Anal Calcd for $\mathrm{C}_{14} \mathrm{H}_{12} \mathrm{~N}_{4} \mathrm{O}_{5} \mathrm{Cl}_{2}: \mathrm{C}, 43.41 ; \mathrm{H}$, $3.10 ; \mathrm{N}, 14.4$. Found: $\mathrm{C}, 43.25 ; \mathrm{H}, 3.27 ; \mathrm{N}, 14.03$.

\section{6,7-Dichloro-2-cyclopropylamino-1-( $\beta$-D-ribofuranosyl)- imidazo $[4,5-b]$ quinoxaline (4d)}

$\mathrm{POCl}_{3}(0.21 \mathrm{~mL}, 2.27 \mathrm{mmol})$ was added in one portion to a solution of triazole $(0.72 \mathrm{~g}, 10.4 \mathrm{mmol})$ in dry acetonitrile $(23 \mathrm{~mL})$ to give a white suspersion. The suspension was then cooled in an ice bath and triethyl amine $(1.39 \mathrm{~mL}$, $9.97 \mathrm{mmol}$ ) was added dropwise. The suspension was brought to room temperature and 6,7-dichloro-1-(2,3,5-tri$O$-benzoyl- $\beta$-D-ribofuranosyl)imidazo[4,5-b]quinoxalin-2one (8a, $0.4 \mathrm{~g}, 0.57 \mathrm{mmol})$ was added. The suspension was then stirred at room temperaturc for 40 hours to give a yellow suspension which was diluted with dry dichloromethane $(17 \mathrm{~mL})$ to give a clear dark-brown solution. $\mathrm{Cy}$ clopropylamine ( $4 \mathrm{~mL}$ ) was then added and the reaction soJution was stirred at room temperature for 4 hours. The solvent was evaporated and the residue was subjected to silica 
gel chromatography $(5 \times 7 \mathrm{~cm})$ with elution by chloroform. The appropriate fractions, as determined by TLC, were collected and the solvent was evaporated to give 6,7 -dichloro2-cyclopropylamino-1-(2,3,5-tri- $O$-benzoyl- $\beta$-D-ribofuranosyl)imidazo $\{4,5-b]$ quinoxaline $(10,0.336 \mathrm{~g}, 80 \%)$ as a bright yellow solid: Mp: $113-115^{\circ} \mathrm{C}$.

Compound $10(0.3 \mathrm{~g})$ was stirred in a saturated methanolic ammonia solution at room temperature for 24 hours. The solvent was evaporated and the residue was triturated with hexane $(2 \times 30 \mathrm{~mL})$. The hexane was decanted and the solid was dried under $0.01 \mathrm{mmHg} / 78^{\circ} \mathrm{C}$ for 24 hours. The solid was recrystallized from methanol to give 6,7-dichloro-2-cyclopropylamino-1-( $\beta$-D-ribofuranosyl)imidazo $[4,5-b]$ quinoxaline (4d, $97 \mathrm{mg}$ ). The mother liquor was subjected to silica gel chromatography $(3 \times 5 \mathrm{~cm})$ with clution by $1 \%$ methanol in chloroform. The appropriate fractions were collected and the solvent was evaporated to give an additional quantity of $4 \mathbf{d}(37 \mathrm{mg})$. The total yicld of 4d was 77.3\%: Mp: $196-198{ }^{\circ} \mathrm{C}$. ${ }^{2} \mathrm{H}$ NMR (DMSO- $d_{6}$ ) $\delta$ $8.629(\mathrm{bs}, 1 \mathrm{H}), 8.091(\mathrm{~s}, 1 \mathrm{H}), 8.081(\mathrm{~s}, 1 \mathrm{H}), 6.017(\mathrm{~d}, J=7.6$ $\mathrm{Hz}, 1 \mathrm{H}), 5.985$ (bs, 1H), 5.457 (d, $J=5.7 \mathrm{~Hz}, 1 \mathrm{H}), 5.272$ (d, $3.9,1 \mathrm{H}), 4.565(\mathrm{q}, J=5.6,1 \mathrm{H}), 4.140(\mathrm{~m}, 1 \mathrm{H}), 4.039$ (bs, $1 \mathrm{H}), 3.686(\mathrm{~m}, 2 \mathrm{H}), 3.072(\mathrm{~m}, 1 \mathrm{H}), 0.825(\mathrm{~m}, 2 \mathrm{H}), 0.685(\mathrm{~m}$, $2 \mathrm{H}) .{ }^{13} \mathrm{C}$ NMR (DMSO- $\left.d_{6}\right) \delta 161.09,152.86,144.28$, $139.52,136.03,128.33,128.09,127.72,127.25,86.45$, $85.93,71.21,70.64,61.46,25.44,6.25,5.91$. UV $\left[\lambda_{\max }, \mathrm{nm}\right.$ $(\varepsilon)]$ : (MeOH) $366.6(13500), 351.0(12000), 268.0(12800)$, 263.0 (12400), 227.2 (40200). Anal. Calcd for $\mathrm{C}_{17} \mathrm{H}_{17} \mathrm{~N}_{5} \mathrm{O}_{4} \mathrm{Cl}_{2} ; \mathrm{C}, 47.89 ; \mathrm{H}, 3.99 ; \mathrm{N}, 16.43$. Found: $\mathrm{C}$, $47.65 ; \mathrm{H}, 3.99 ; \mathrm{N}, 16.35$.

\section{6,7-Dichloro-2-isopropylamino-1-(3-D-ribofuranosyl)imi- dazo $[4,5-b] q u i n o x a l i n e ~(4 e)$}

$\mathrm{POCl}_{3}(0.16 \mathrm{~mL}, 1.7 \mathrm{mmol})$ was added in one portion to a solution of 1,2,4-triazole $(0.54 \mathrm{~g}, 7.8 \mathrm{mmol})$ in dry acetonitrile (17 mL) to give a white suspension. The suspension was then cooled in an ice bath and triethylamine (1.04 $\mathrm{mL}, 7.5 \mathrm{mmol}$ ) was added dropwise. The suspension was brought to room temperature and 6,7-dichloro-1-(2,3,5-tri$O$-benzoyl- $\beta$-D-ribofuranosyl)imidazo $[4,5-b]$ quinoxalin-2one ( $8 \mathrm{a}, 0.3 \mathrm{~g}, 0.43 \mathrm{mmol}$ ) was added. The suspension was then stirred at room temperature for 54 hours to give a yellow suspension. This suspension was diluted with dry dichloromethane $(14 \mathrm{~mL})$ to give a clear brown solution. Isopropylamine $(4 \mathrm{~mL})$ was then added and the reaction solution was stitred at room temperature for 3 hours. The solvent was evaporated and the residue was dissolved in chloroform and filtered through a short silica gel column to remove the salt. The silica gel bed was washed with $1 \%$ methanol in chloroform until the filtrate was devoid of UV absorption. The filtrate was evaporated and the residue was subjected to silica gel chromatography $(5 \times 7 \mathrm{~cm})$ with elution by chloroform. The appropriate fractions, as determined by TLC, were collected and the solvent was evaporated to give 6,7-dichloro-2-isopropylamino-1-(2,3,5-tri- $O$ benzoyl- $\beta$-D-ribofuranosyl)imidazo $[4,5-b]$ quinoxaline (11, $0.22 \mathrm{~g}, 68 \%)$ as a yellow solid.

Compound $11(0.202 \mathrm{~g})$ was stirred in a saturated methanolic ammonia solution $(100 \mathrm{~mL})$ at room temperature for 24 hours. The solvent was evaporated and the residue was triturated with hexane $(2 \times 40 \mathrm{~mL})$. The hexane was decanted and the solid was dried under $0.01 \mathrm{mmHg} / 78$ ${ }^{\circ} \mathrm{C}$ for 24 hours. The solid was recrystallized from a mixture of acetonitrile $(10 \mathrm{~mL})$ and ethanol $(4 \mathrm{~mL})$ to give $6,7-\mathrm{di}$ chloro-2-isopropylamino-1-( $\beta$-D-ribofuranosyl)imidazo$[4,5-b]$ quinoxaline $(4 \mathrm{e}, 92 \mathrm{mg})$. The mother liquor was subjected to silica gel chromatography $(3 \times 5 \mathrm{~cm})$ with elution by $1 \%$ methanol in chloroform. The appropriate fractions, as determined by TLC, were collected and the solvent was evaporated to give an additional quantity of $4 \mathrm{e}(8.7 \mathrm{mg})$. The total yield of $4 \mathrm{e}$ was $81 \%$; Mp: decompose above 240 ${ }^{\circ} \mathrm{C}$. ' ${ }^{1}$ NMR (DMSO- $\left.d_{6}\right) 88.415(\mathrm{~d}, J=7.7 \mathrm{~Hz}, 1 \mathrm{H}), 8.072$ (s, 1H), $8.051(\mathrm{~s}, 1 \mathrm{H}), 6.136(\mathrm{~d}, J=7.6 \mathrm{~Hz}, 1 \mathrm{H}), 5.965$ (bs, $1 \mathrm{H}), 5.468(\mathrm{~s}, J=5.8 \mathrm{~Hz}, 1 \mathrm{H}), 5.279(\mathrm{~d}, J=4.0 \mathrm{~Hz}, 1 \mathrm{H})$, $4.619(q, J=5.3 \mathrm{~Hz}, 1 \mathrm{H}), 4.342(\mathrm{~m}, 1 \mathrm{H}), 4.166(\mathrm{~m}, 1 \mathrm{H})$, $4.057(\mathrm{bs}, 1 \mathrm{H}), 3.707$ (bs, 2H), $1.281(\mathrm{~d}, J=6.4 \mathrm{~Hz}, 6 \mathrm{H})$. ${ }^{13}$ C NMR (DMSO- $d_{6}$ ) $\delta 159.49,152.94,144.47,139.57$, $136.00,128.21,127.96,127.67,127.01,86.38,85.92$, $71.23,70.61,61.50,45.19,22.14,22.05$. UV $\left[\lambda_{\max }, \operatorname{nm}(\varepsilon)\right]$ : (MeOH) 368.0 (29600), 356.0 (28500), 270.0 (25400), 263.2 (26400), 225.8 (50800). Anal. Calcd for $\mathrm{C}_{17} \mathrm{H}_{4} \mathrm{~N}_{5} \mathrm{O}_{4} \mathrm{Cl}_{2}: \mathrm{C}, 47.66 ; \mathrm{H}, 4.44 ; \mathrm{N}, 16.36$. Found: $\mathrm{C}$, $47.68 ; \mathrm{H}, 4.45 ; \mathrm{N}, 16.26$.

\section{6,7-Dichloro-1-(2,3,5-tri- $O$-benzoyl- $\beta$-D-ribofuranosyi)- imidazo[4,5-b]quinoxalin-2-thione (12a)}

Phosphorus oxychloride ( $1.06 \mathrm{~mL}, 11.5 \mathrm{mmol}$ ) was added to a solution of 1,2,4-triazole $(3.62 \mathrm{~g}, 52.4 \mathrm{mmol})$ in dry acetonitrile $(110 \mathrm{~mL})$ to give a white suspension. The suspension was first cooled in an ice bath and triethyl amine (6.94 $\mathrm{mL}, 49.8 \mathrm{mmol}$ ) was added dropwise. After stirring in an ice bath for 5 minutes, the suspension was brought back to room temperature and 6,7-dichloro-1-(2,3,5-tri- $O$-benzoyl- $\beta$-D-ribofuranosyl)imidazo[4,5-b]quinoxalin-2-one $(8 \mathrm{a}, 2.0 \mathrm{~g}, 2.9 \mathrm{mmol})$ was added in one portion. The suspension was then stirred at room temperature for 3 days to give a yellow suspension. Hydrogen sulfide was bubbled into the suspension for 5 minutes and the reaction flask was 
sealed with a rubber stopper and stirred at room temperature for 30 minutes. The suspension was then concentrated to about $20 \mathrm{~mL}$ and diluted with chloroform $(500 \mathrm{~mL})$. The chloroform solution was washed sequentially with a saturated sodium bicarbonate solution $(2 \times 200 \mathrm{~mL})$, water $(4 \times$ $300 \mathrm{~mL}$ ), a saturated sodium chloride solution, and dried over anhydrous sodium sulfate. The solvent was evaporated to give a yellow solid which was recrystallized from ethyl acetate to give 6,7-dichloro-1-(2,3,5-tri- $O$-benzoyl- $\beta$-D-ribohuranosyl)imidazo[4,5-b]quinoxalin-2-thione (12a, 1.35 $\mathrm{g}, 65.9 \%)$ as a yellow solid. The mother liquor was then subjected to silica gel chromatography $(3 \times 7 \mathrm{~cm})$ and eluted with $0.5 \%$ methanol in chloroform. The corresponding fractions, as identifted by TLC, were collected and evaporated to dryness to give an additional quantity of 12a $(0.27$ g. 13.2\%). The total yield was 79\%: Mp: decompose above $290^{\circ} \mathrm{C}$. ${ }^{~} \mathrm{H}$ NMR (DMSO- $\left.d_{6}\right) ; \delta 14.326(\mathrm{bs}, 1 \mathrm{H}$, ), 8.255 (s, 1H), $7.981(\mathrm{~s}, 1 \mathrm{H}), 7.943-7.250(\mathrm{~m}, 15 \mathrm{H}), 6.945(\mathrm{~d}, J=2.9$ $\mathrm{Hz}, 1 \mathrm{H}), 6.654(\mathrm{t}, J=6.6 \mathrm{~Hz}, 1 \mathrm{H}), 6.562(\mathrm{dd}, J=2.9 \mathrm{~Hz}, J=$ $5.7 \mathrm{~Hz}, 1 \mathrm{H}), 4.912(\mathrm{~m}, 1 \mathrm{H}), 4.811(\mathrm{dd}, J=3.14 \mathrm{~Hz}, J=12.7$ $\mathrm{Hz}, 1 \mathrm{H}), 4.730(\mathrm{dd}, J=4.23 \mathrm{~Hz}, J=12.4 \mathrm{~Hz}, 1 \mathrm{H})$. Anal. Calcd for $\mathrm{C}_{35} \mathrm{H}_{24} \mathrm{~N}_{4} \mathrm{O}_{7} \mathrm{SCl}_{2}: \mathrm{C}, 58.74 ; \mathrm{H}, 3.36 ; \mathrm{N}, 7.83$. Found: C, 58.62; H, 3.62; N, 7.89 .

\section{6,7-Dichloro-1-( $\beta$-D-ribofuranosyl)imidazo[4,5-b]quinox- alin-2-thione (12b)}

6,7-Dichloro-1-(2,3,5-tri- $O$-benzoyl- $\beta$-D-riboturanosyl)imidazo[4,5-b] quinoxalin-2-thione (12a, $0.4 \mathrm{~g}, 0.57 \mathrm{mmol}$ ) was stirred with sodium methoxide $(0.127 \mathrm{~g}, 2.4 \mathrm{mmol})$ in methanol $(50 \mathrm{~mL})$ at room temperature for 2 hours to give a brown solution. Acetic acid $(0.16 \mathrm{~mL}, 2.8 \mathrm{mmol})$ was added and the solution was stirred for 5 minutes. The solvent was evaporated and the yellow solid was triturated with hexane $(3 \times 40 \mathrm{~mL})$. The hexane was decanted, and the solid was dried under $0.01 \mathrm{~mm} \mathrm{Hg} / 78^{\circ} \mathrm{C}$ for 24 hours and stirred in water $(50 \mathrm{~mL})$ at room temperature for 30 minutes. The solid was collected by filtration and dried under vacuum. The solid was then recrystallized from acetonitrile and ethanol ( $18 \mathrm{~mL} / 13 \mathrm{~mL})$ to give 6,7 -dichloro-1-( $\beta$-D-ribofuranosyl)imidazo[4,5-b]quinoxalin-2-thione (12b, $0.189 \mathrm{~g}, 84 \%)$ as a yellow solid: Mp: decompose above $240{ }^{\circ} \mathrm{C}$. ' $\mathrm{H}$ NMR (DMSO-d $\left.d_{6}\right) ; 14.184$ (bs, 1H), $8.249(\mathrm{~s}, 1 \mathrm{H}), 8.137(\mathrm{~s}, 1 \mathrm{H}$.), $6.445(\mathrm{~d}, J=5.0 \mathrm{~Hz}, 1 \mathrm{H}), 5.322(\mathrm{~d}, J=5.0 \mathrm{~Hz}, 1 \mathrm{H}), 5.159$ (d, 1H), $5.082(\mathrm{~m}, 1 \mathrm{H}), 4.810(\mathrm{bs}, 1 \mathrm{H}), 4.425(\mathrm{~m}, 1 \mathrm{H}), 3.932$ $(\mathrm{m}, 1 \mathrm{H}), 3.775(\mathrm{~m}, \mathrm{lH}), 3.600(\mathrm{~m}, \mathrm{lH}),{ }^{13} \mathrm{C}$ NMR (DMSO$\left.d_{6}\right): \delta 177.30,142.58,141.17,138.11,136.94,130.11$, $129.75,128.56,128.28,88.76,85.41,70.52,70.37,61.92$. Anal. Calcd for $\mathrm{C}_{14} \mathrm{H}_{12} \mathrm{~N}_{4} \mathrm{O}_{4} \mathrm{SCl}_{2} 0.25 \mathrm{H}_{2} \mathrm{O}: \mathrm{C}, 41.23 ; \mathrm{H}$, 3.07; N, 13.74. Found: C, 41.08; H, 3.15; N, 13.36 .

\section{2-Benzylthio-6,7-dichloro-1-( $\beta$-D-ribofuranosyl)imi- dazo $[4,5-b]$ quinoxaline $(4 c)$}

Benzyl bromide $(0.36 \mathrm{~mL}, 3.0 \mathrm{mmol})$ was added to a solution of 6,7-dichloro- 1 - $(\beta$-D-ribofuranosyl)imidazo[4,5b] quinoxalin-2-thione $(12 \mathrm{~b}, 0.61 \mathrm{~g}, 1.51 \mathrm{mmol})$ in the presence of concentrated ammonium hydroxide (about $2 \mathrm{~mL}$ ) in water $(20 \mathrm{~mL})$. The reaction mixture was stirred at room temperature for 2 hours to give a slightly yellow suspension. The solid was collected by filtration, washed with water and dried under vacuum. The solid was then recrystallized from n-butanol to give 2-benzylthio-6,7-dichloro-1-( $\beta$-D-ribofuranosyl)imidazo[4,5-b]quinoxaline $(4 \mathrm{c}, 0.397 \mathrm{~g}, 53 \%)$ as a slightly yellow solid: $\mathrm{Mp}$ : decompose above $220^{\circ} \mathrm{C} .{ }^{1} \mathrm{H}$ NMR (DMSO- $\left.d_{6}\right): \delta 8.397(\mathrm{~s}, 1 \mathrm{H}), 8.273(\mathrm{~s}, 1 \mathrm{H}), 7.699-$ $7.282(\mathrm{~m}, 5 \mathrm{H}), 5.837(\mathrm{~d}, J=6.2 \mathrm{~Hz}, 1 \mathrm{H}), 5.533(\mathrm{~d}, J=5.9$ $\mathrm{Hz}, 1 \mathrm{H}), 5.311(\mathrm{~d}, J=5.0 \mathrm{~Hz}, 1 \mathrm{H}), 4.917(\mathrm{l}, J=5.9 \mathrm{~Hz}, 1 \mathrm{H})$, $5.143(\mathrm{q}, J=5.8 \mathrm{~Hz}, 1 \mathrm{H}), 4.807(\mathrm{~m}, 2 \mathrm{H}), 4.296(\mathrm{~m}, J=2.7$ $\mathrm{Hz}, J=5 \mathrm{~Hz}, 1 \mathrm{H}), 3.969(\mathrm{~m}, J=2.7 \mathrm{~Hz}, J=5.3 \mathrm{~Hz}, 1 \mathrm{H})$, $3.736(\mathrm{~m}, 1 \mathrm{H}), 3.597(\mathrm{~m}, 1 \mathrm{H}),{ }^{13} \mathrm{C}$ NMR (DMSO- $\left.d_{6}\right): \delta$ $168.63,150.60,143.12,138.99,136.66,136.38,130.13$, $129.29,128.61,128.34,127.76,88.95,86.24,70.63,70.42$, 61.73, 35.54. UV $\left[\lambda_{\max } \mathrm{nm}(\varepsilon)\right]:(\mathrm{MeOH}) 372.6(35600)$, 356.0 (26100), $269.6(16700), 226.4(54100), 204.0$ (23500). Anal. Calcd for $\mathrm{C}_{21} \mathrm{H}_{18} \mathrm{~N}_{4} \mathrm{O}_{4} \mathrm{SCl}_{2}: \mathrm{C}, 51.12 ; \mathrm{H}$, $3.65 ; \mathrm{N}, 11.36$. Found: $\mathrm{C}, 50,96 ; \mathrm{H}, 3.81 ; \mathrm{N}, 11.17$.

\section{6,7-Dichloro-1-( $(3-\mathrm{D}-$-ribofuranosyl)imidazo[4,5-b]quinox- aline (4f)}

6,7-Dichloro-1-( $\beta$-D-ribofuranosyl)imidazo[4,5-b]quinoxalin-2-thione $(12 \mathrm{~b}, 130 \mathrm{mg}, 0.32 \mathrm{mmol})$ was dissolved in methanol $(60 \mathrm{~mL})$ with heating. Raney nickel ( 2.6 $\mathrm{g}$, wet paste) was added and the reaction mixture was heated at reflux for one hour. The reaction mixture was cooled to room temperature and filtered through Celite. The filtrate was evaporated under reduced pressure and the residue was subjected to silica gel chromatography $(5 \times 5 \mathrm{~cm})$ by elution with $10 \%$ of methanol in chloroform. The appropriate fractions were collected, as determined by TLC, and evaporated under reduced pressure to give 6,7-dichloro-1-( $\beta$-D-ribofuranosyl)imidazo[4,5-b]quinoxaline $(\mathbf{4 f}, 63 \mathrm{mg}, 52.2 \%)$ as a slightly brown solid: $\mathrm{Mp}$ : decompose above $180^{\circ} \mathrm{C}$. ${ }^{1} \mathrm{H}$ NMR (DMSO- $d_{6} \delta 9.487(\mathrm{~s}, 1 \mathrm{H}), 8.510(\mathrm{~s}, 1 \mathrm{H}), 8.457$ (s, $1 \mathrm{H}), 6.125(\mathrm{~d}, J=4.5 \mathrm{~Hz}, 1 \mathrm{H}), 5.587(\mathrm{~d}, J=5.4 \mathrm{~Hz}, 1 \mathrm{H})$, $5.287(\mathrm{~d}, J=4.1 \mathrm{~Hz}, 1 \mathrm{H}), 5.118(\mathrm{t}, J=4.7 \mathrm{~Hz}, 1 \mathrm{H}), 4.689(\mathrm{q}$, $J=5.0 \mathrm{~Hz}, 1 \mathrm{H}), 4.253(\mathrm{q}, J=4.8 \mathrm{~Hz}, 1 \mathrm{H}), 4.013(\mathrm{~m}, 1 \mathrm{H})$, $3.740(\mathrm{~m}, 1 \mathrm{H}), 3.626(\mathrm{~m}, 1 \mathrm{H}),{ }^{13} \mathrm{C}$ NMR (DMSO- $\left.d_{6}\right) \delta$ $155.09,151.20,141.30,139.41,137.92,131.26,130.37$, $129.81,128.72,87.91,85.59,73.45,70.12,51.04$. UV $\left[\lambda_{\max }, \mathrm{nm}(\varepsilon)\right]:(\mathrm{MeOH}) 354.0(15100), 339.8(15400), 248.8$ 
(29700), 222.8 (46800). Anal. Calcd for $\mathrm{C}_{14} \mathrm{H}_{12} \mathrm{~N}_{4} \mathrm{O}_{4} \mathrm{Cl}_{2}: \mathrm{C}$, $45.28 ; \mathrm{H}, 3.23 ; \mathrm{N}, 15.09$. Found: C, $44.90 ; \mathrm{H}, 3.45 ; \mathrm{N}$, 14.83 .

\section{Cell Culture Procedures}

The routine growth and passage of $\mathrm{KB}, \mathrm{BSC}-1$ and $\mathrm{HFF}$ cells was performed in monolayer cultures using minimal essential medium (MEM) with either Hanks salts [MEM(H)] or Earle salts [MEM(E)] supplemented with $10 \%$ calf serum or $10 \%$ fetal bovine serum (HFF cells). The sodium bicarbonate concentration was varied to meet the buffering capacity required. Cells were passaged at 1:2 to $1: 10$ dilutions according to conventional procedures by using $0.05 \%$ trypsin plus $0.02 \%$ EDTA in a HEPES buffered salt solution.

\section{Virological Procedures}

The Towne strain, plaque-purified isolate $P_{a}$ of HCMV was kindly provided by Dr. Mark Stinski, University of Iowa. The KOS strain of HSV-1 was used in most experiments and was provided by Dr. Sandra K. Weller, University of Connecticut. Stock HCMV was prepared by infecting HFF cells at a multiplicity of infection (m.o.i.) of $<$ 0.01 plaque-forming units (p.f.u.) per cell as detailed previously. ${ }^{23}$ High titer HSV-I stocks were prepared by infecting $K B$ cells at an m.o.i. of < 0.1 also as detailed previously. ${ }^{23}$ Virus titers were determined using monolayer cultures of HFF cells for HCMV and monolayer cultures of BSC-1 cells for HSV-1 as described earlier. ${ }^{24}$ Briefly, $\mathrm{HFF}$ or BSC-1 cells were planted as described above in 96-well cluster dishes and incubated overnight at $37^{\circ} \mathrm{C}$. The next day cultures were inoculated with HCMV or HSV-1 and serially diluted $1: 3$ across the remaining eleven columns of the 96-well plate. After virus adsorption the inoculum was replaced with fresh medium and cultures were incubated for seven days for HCMV, two or three days for HSV-1. Plaques were enumerated under 20-fold magnification in wells having the dilution which gave 5 to 20 plaques per well. Virus titers were calculated according to the following formula: Titer (p.f.u. $/ \mathrm{mL}$ ) $=$ number of plaques $\times 5 \times 3^{n}$; where $n$ represents the $n$th dilution of the virus used to infect the well in which plaques were enumerated.

\section{HCMV Plaque Reduction Assay}

HFF cells in 24-well cluster dishes were infected with approximately 100 p.f.u. of HCMV per $\mathrm{cm}^{2}$ cell sheet using the procedures detailed above. Following virus adsorption, compounds dissolved in growth medium were added to duplicate wells in four to eight selected concentrations. After incubation at $37^{\circ} \mathrm{C}$ for 10 days, cell sheets were fixed, stained with crystal violet and microscopic plaques enumerated as described above. Drug effects were calculated as a percentage of reduction in number of plaques in the presence of each drug concentration compared to the number observed in the absence of drug.

\section{HSV-1 ELISA}

An ELISA was employed to detect HSV-1.25 Ninetysix-well cluster dishes were planted with $10,000 \mathrm{BSC}-1$ cells per well in $200 \mu \mathrm{L}$ per well of MEM(E) plus $10 \%$ calt serum. After ovenight incubation at $37^{\circ} \mathrm{C}$, selected drug concentrations in quadruplicate and HSV-1 at a concentration of 100 p.f.u./well were added. Following a three day incubation at $37^{\circ} \mathrm{C}$, medium was removed, plates were blocked, rinsed, and horse radish peroxidase conjugated rabbit anti-HSV-1 antibody was added. Following removal of the antibody containing solution, plates were rinsed, and then developed by adding $150 \mu \mathrm{L}$ per well of a solution of tetramethylbenzidine as substrate. The reaction was stopped with $\mathrm{H}_{2} \mathrm{SO}_{4}$ and absorbence was read at 450 and 570 nm. Drug effects were calculated as a percentage of the reduction in absorbence in the presence of each drug concentration compared to absorbence obtained with virus in the absence of drug.

\section{Cytotoxicity Assays}

Two different assays were used to examine cytotoxicity of selected compounds by methods we have detailed previously. (i) Cytotoxicity produced in stationary HFF cells was determined by microscopic inspection of cells not affected by the virus used in plaque assays. ${ }^{23}$ (ii) The effect of compounds during two population doublings of $\mathrm{KB}$ cells was determined by crystal violet staining and spectrophotometric quantitation of dye eluted from stained cells as described earlier. ${ }^{26}$ Briefly, 96-well cluster dishes were planted with $\mathrm{KB}$ cells at $3000-5000$ cells per well. After overnight incubation at $37^{\circ} \mathrm{C}$, test compounds were added in quadruplicate at six to eight concentrations. Plates were incubated at $37^{\circ} \mathrm{C}$ for 48 hours in a $\mathrm{CO}_{2}$ incubator, rinsed, fixed with $95 \%$ ethanol, and stained with $0.1 \%$ crystal violet. Acidified ethanol was added and plates read at $570 \mathrm{~nm}$ in a spectrophotometer designed to read 96-well ELISA assay plates.

\section{Data Analysis}

Dose-response relationships were constructed by linearly regressing the percent inhibition of parameters derived in the preceding sections against log drug concentrations. Fifty-percent inhibitory concentrations ( $\mathrm{IC}_{50}$ ) or IC $\mathrm{C}_{90}$ 's were calculated from the regression lines. Samples containing 
positive controls (acyclovir for HSV-1, ganciclovir for HCMV, and 2-acetylpyridine thiosemicarbazone for cytotoxicity) were used in all assays.

\section{ACKNOWLEDGMENTS}

The authors would like to thank Julie M. Breitenbach and Roger G. Ptak for expert performance of antiviral and cytotoxicity assays and Marina Savic for the preparation of this manuscript. This research was supported by Research Grant U19-A131718 from the National Institute of Allergy and Infections Diseases, National Institute of Health.

Received February 2, 1998.

Key Words

Herpes; Antivirals; Nuclcosides; Benzimidazole; Imidazo $[4,5-b]$ quinoxaline; Polyhalogenated.

\section{RETERENCES}

1. Alford, C. A.; Britt, W. J. Cytomegalovirus, in The Human Herpesviruses; Roizman, B., Whitley, R. J., Lopez, C., Eds.; Raven Press: New York, 1993; pp 7-255.

2. Alford, C. A.; Stagno, S.; Pass, R. F.; Britt, W. J. Congenital and perinatal cytomegalovirns infections. Rev. Infect. Dis. 1990, 12, S745-S753.

3. Wingard, J. R.; Piantadosi, S.; Burns, W. H.; Zahurak, M. L.; Santos, G. W.; Saral, R. Cytomegalovirus infections in bone marrow transplant recipients given intensive cytoreductive therapy. Rev. Infect. Dis. 1990, I2, S793-S804.

4. Rubin, R. H. Impact of cytomegalovirus infection on organ transplant recipients. Rev. Infect. Dis. 19y0, 12, \$754-S766.

5. Gallant, J. E.; Moore, R. D.; Richman, D. D.; Keruly, J.; Chaisson, R. E. et al. Incidence and natural history of cytomegalovirus disease in patients with advanced human immunodeficiency virus disease treated with zidovudine. J. Infect. Dis. 1992, I66, 1223-1227.

6. (a) Faulds, D.; Heel, R. C. Ganciclovir. A Review of its Antiviral Activity, Pharmacokinetic Properties and Therapeutic Efficacy in Cytomegalovirus Infections. Drugs 1990, 39, 597-638. (b) Chrisp, P.; Clissold, S. P. Foscarnet. A review of its antiviral activity, pharmacokinetic properties and therapeutic use in immunocompromised patients with cytomegalovirus retinitis. Drugs
1991, 4I, 104-129.

7. Field, A. K.; Biron, K. K. "The End of Innocence" Revisited: Resistance of Herpesviruses to Antiviral Drugs. Clin. Microbiol. Rev. 1994, 7, 1-13.

8. (a) Millar, A. B.; Miller, R. F.; Patou, G.; Mindel, A.; Marsh, R.; Semple, S. J. Treatment of cytomegalovirus retinitis with zidovudine and ganciclovir in patients with AIDS: outcome and toxicity. Genitourin. Med. 1990, $66,156-158$.

9. (a) Townsend, L. B.; Drach, J. C. and coworkers presented at the Fifth Internat. Conf. Antiviral Res., Vancouver, BC, 1992, Abstracts 12, 105, 107, 108, 110. (b) Townsend, L. B.; Devivar, R. V.; Turk, S. R.; Nassiri, M. R.; Drach, J. C. Design, Synthesis and Antiviral Activity of Certain 2,5,6-trihalo-1-( $\beta$-D-ribofuranosyl)benzimidazoles. J. Med. Chem. 1995, 38, 4098-4105.

10. Devivar, R. V.; Kawashima, E.; Revankar, G. R.; Breitenbach, J. M.; Kreske, E. D.; Drach, J. C.; Townsend, L. B. Benzimidazole ribonucleosides: Design, synthesis and antiviral evaluation of certain 2-(alkylthio)- and 2-(benzylthio)-5,6-dichloro-1-( $\beta$-D-riboturanosyl)benzimidazoles. J. Med. Chem. 1994, 37, 2942-2949.

11. Nassiri, M. R.; Emerson, S. G; Devivar, R. V.; Townsend, L. B.; Drach, J. C.; Taichman, R. S. Comparison of benzimidazole nucleosides and ganciclovir on the in vitro proliferation and colony formation of human bone marrow progenitor cells. Brit. J. Haematol. 1996, 93, 273-279.

12. 'lamm, I; Folkers, K.; Shunk, C. H.; Horsfall, F. L. Inhibition of influenza virus multiplication by $\mathrm{N}$-giycosides of benzimidazoles. J. Exp. Med. 1954, 99, 227-250.

13. (a) Underwood, M. R.; Biron, K. K.; Hemphill, M. L.; Miller, T. J.; Stanat, S. C.; Dornsife, R. E.; Drach, J. C.; Townsend, L. B.; Edwards, C. A.; Harvey, R. J. High Molecular Weight HCMV DNA Does Not Properly Mature in the Presence of 2-Bromo-5,6-dichloro-1- $\beta$-D-ribofuranosylbenzimidazole (BDCRB), Presented at the Herpesvirus Workshop, Pittsgurgh, PA, July 1993. (b) Underwood, M. R.; Stanat, S. C.; Drach, J. C.; Harvey, R. J.; Biron, K. K. Inhibition of HCMV DNA processing by a new ciass of anti-HCMV compounds is mediatcd through the UL89 gene product. Presented at the Herpesvirus Workshop, Vancouver, BC, August 1994.

14. Biron, K. K.; Davis, M. G.; Stanat, S. C.; Walton, L. M.; Smith, A.; Koszalka, G. W.; Drach, J. C.; Townsend, L. B.; Harvey, R. J. Antiviral activity and mechanism of action of $12063 \mathrm{~W} 94$, A benzimidazole riboside inhibitor of human cytomegalovirus. 36th Interscience Conf. Antimicrob. Agents Chemother, New Orleans, LA; September 1996. 
15. Zhu, Z.; Lippa, B.; Drach, J. C.; Townsend, L. B. Synthesis of imidazo[4,5-b]quinoline nucleosides as linear tricyclic analogs of TCRB and BDCRB. 210th Amer. Chem. Soc. Div. Med. Chem. National Meeting, Chicago, IL, August 1995.

16. Cheeseman, G. W. H. Quinoxalines and Related Compounds. Part VI. Substitution of 2,3-Dihydroxyquinoxaline and its 1,4-Dimethylderivative. J. Chem. Soc. 1962, 1170-1176.

17. Schipper, E.; Day, A. R. Studies in Imidazoles. I. Imidazo(b)quinoxalines. J. Am. Chem. Soc, 1951, 73, 56725675 .

18. Cheeseman, G. N. H.; Cookson, R. F. Condensed Pyrazines in the Chemistry of Heterocyclic Compounds, Weissberger, A.; Taylor, E. C. Eds, John Wiley \& Sons, Inc., New York, 1979, pp 663-671.

19. Vorbruggen Method: (a) Vorbruggen, H.; Krolikiewicz, K.; Bennua, B. Nucleoside Synthesis XXII, Nucleoside Synthesis with Trimethylsilyl Triflate and Perchlorate as Catalysts. Chem. Ber. 1981, 114, 1234-1255. (b) Vorbruggen, H.; Bennua, B. Nucleoside Synthesis XXV. A New Simpinfied Nucleoside Synthesis. Chem. Ber. 1981, 14, 1279-1286. (c) Dudycz, L.; Wright, G. E. A Simple One-pot Method for 6-Oxopurine Ribonucleoside Synthesis: Control and Mechanism of Isomer Distribution. Nacleosides Nucleotides 1984, 3, 33-44.

20. (a) Cline, B ; Fagerness, P. E.; Panzica, R. P.; Townsend, L. B. The use of Carbon-13 Magnetic Resonance Chemical Shifts and Long-range ${ }^{13} \mathrm{C}-{ }^{1} \mathrm{H}$ Constants for Assigning the Site of Glycosylation of Nitrogen Heterocycles. J. Chem. Soc. Perkin, II, 1980, 1586-1591. (b) Kalinowski, H.-O.; Gerger, S.; Braun, S. Carbon-13
Spectroscopy John Wiley \& Son Inc, 1986, pp 57-59. (c) Bock, K.; Pederson, C. Assignment of Long-range Carbonproton Couplings through Selective Proton Decoupling. J. Magn. Reson. 1977, 5, 227-230.

21. Divakar, K. J.; Reese, C. 4-(1,2,4-Triazol-1-yl)- and 4(3-nitro-1,2,4-triazol-1-yl)-1-( $\beta$-D-2,3,5-tri- $O$-acetylarabinofuranosyl)pyrimidin-2(1H)-ones. Valuable Intermediates in the Synthesis of Derivatives of $1-(\beta-D-$ Arabinofuranosyl)cytosine (AraC), J. Chem. Soc. Perkin Trans., I, 1982, 1171-1176.

22. Robins, R. K. A New Synthesis of Chloropurine Ribonucleosides. J. Am. Chem. Soc. 1960, 82, 2654-2655.

23. Turk, S. R.; Shipman, C., Jr.; Nassiri, M. R.; Genzingler, G.; Krawczyk, S. H.; Townsend, L. B.; Drach, J. C. Pyrrolo[2,3-d]pyrimidine Nucleosides as Inhibitors of $\mathrm{Hu}$ Inan Cytomegalovirus. Antimicrob. Agents Chemother. 1987, 31, 544-550.

24. Prichard, M. N.; Turk, S. R.; Coleman, L. A.; Engelhardt, S. L.; Shipman, C., Jr; Drach, J. C. A Microtiter Virus Yield Reduction Assay for The Evaluation of Antiviral Compounds Against Human Cytomegalovirus and Herpes Simplex Virus. J. Virol. Methods, 1990, 28, $101-106$.

25. Prichard, M. N.; Shipman, C., Jr. A Three-Dimensional Model To Analyze Drug-Drug Interactions. Antiviral Res. 1990, 14, 181-206.

26. Prichard, M. N.; Prichard, L. E.; Baguley, W. A.; Nassiri, M. R.; Shipman, C., Jr. Three-Dimensional Analysis of the Synergistic Cytotoxicity of Ganciclovir and $\mathrm{Zi}$ dovudine. Antimicrob. Agents Chemother. 1991, 35, 1060-1065. 